\title{
Self-esteem of people with venous ulcers
}

\author{
Autoestima de pessoas com úlcera venosa
}

Amanda Jéssica Gomes de Souza ${ }^{1}$, Samilly Márjore Dantas Liberato Campos ${ }^{1}$, Marina Góes Salvetti ${ }^{2}$, Cintia Galvão Queiroz $^{1}$, Gilson de Vasconcelos Torres ${ }^{1}$, Isabelle Katherinne Fernandes Costa ${ }^{1}$

Objective: to verify the level of self-esteem of people with venous ulcer and its relationship with sociodemographic, care and clinical characteristics. Methods: cross-sectional study with 44 patients with venous ulcers assisted in primary health care and evaluated using the Rosenberg Self-Esteem Scale. Descriptive and inferential statistics were performed. The $t$-test was to compare means of the scale scores in relation to sociodemographic, care and clinical characteristics. Results: the mean self-esteem was $9.3( \pm 5.1)$. The variables that showed association with self-esteem were: married/common-law married patients $(p=0.016)$, with occupation $(p=0.023)$, using compressive therapy $(\mathrm{p}=0.040)$, under less than six months of treatment $(\mathrm{p}=0.014)$, and with small ulcers $(p=0.010)$. Conclusion: the self-esteem of patients with venous ulcers was satisfactory/high, and it was especially higher among those with partner, with occupational activity, making use of compressive therapy, at the initial phase of the treatment and who had small ulcers.

Descriptors: Varicose Ulcer; Quality of Life; Delivery of Health Care; Nursing.

Objetivo: verificar o nível de autoestima de pessoas com úlcera venosa e sua relação com características sociodemográficas, assistenciais e clínicas. Métodos: estudo transversal com 44 pacientes com úlceras venosas atendidos na atenção primária à saúde e avaliados mediante a Escala de Autoestima de Rosenberg. Foi realizada estatística descritiva e inferencial dos dados. Utilizou-se o Test $t$ na identificação de diferenças entre as médias dos escores da escala em relação às características sociodemográficas, assistenciais e clínicas. Resultados: a média da autoestima foi 9,3 $( \pm 5,1)$. As variáveis que apresentaram associação com autoestima foram: pessoas casadas/união estável $(p=0,016)$, com ocupação $(p=0,023)$, em uso de terapia compressiva $(p=0,040)$, menos de seis meses de tratamento $(\mathrm{p}=0,014)$ e com úlceras pequenas $(\mathrm{p}=0,010)$. Conclusão: a autoestima dos pacientes com úlceras venosas mostrou-se satisfatória/alta, sendo mais elevada entre aqueles com companheiro, atividade ocupacional, uso de terapia compressiva, na fase inicial de tratamento e que apresentavam úlceras pequenas.

Descritores: Úlcera Varicosa; Qualidade de Vida; Assistência à Saúde; Enfermagem.

\footnotetext{
${ }^{1}$ Universidade Federal do Rio Grande do Norte. Natal, RN, Brazil.

${ }^{2}$ Universidade de São Paulo. São Paulo, SP, Brazil. 


\section{Introduction}

Venous ulcer is defined as a leg or foot injury that occurs in an area affected by venous hypertension, in result of reflux or obstruction of venous return $^{(1)}$. Its incidence has proportionally increased with the longer life expectancy of the world population and its prevalence varies from approximately 0.1 to $2.0 \%$. It has high chronicity and causes significant morbidity due to the difficult cure, with a recurrence of around 15 to $71.0 \%$. In addition, 40 to $70.0 \%$ of the lesions only heal after six months of treatment and, approximately $15.0 \%$, never heal ${ }^{(1-2)}$.

Venous lesions affect young men and women in the same way, but they are more frequent in the elderly and in people with low level of education ${ }^{(3-5)}$. Clinically, they are large, superficial, exudative and painful ulcers, and impose difficulties to locomotion and daily activities and lead to loss of employment ${ }^{(5-6)}$. They may also bring emotional problems such as feelings of fear, shame, inferiority, anxiety, depression, low self-esteem, decreased social interaction and a tendency towards social isolation ${ }^{(6-7)}$. Thus, self-esteem is one of the important aspects to be considered in the evaluation of patients with venous ulcers.

Self-esteem is defined as the attribution of personal value that can be expressed in attitudes of acceptance or rejection and is associated with self-image, personal achievements, success in relationships and personality traits ${ }^{(8-9)}$. It is dynamically built upon the personal relationship with the world and undergo changes throughout life. Low self-esteem can lead to self rejection, dissatisfaction and self-loathing ${ }^{(8)}$.

In this perspective, the present study is relevant because aspects related to the self-esteem of patients with venous ulcer need to be known in order to identify the impact of this type of injury, and qualify the care provided. In this sense, the question raised is: what is the intensity of people with venous ulcer? Thus, the objective was to verify the level of self-esteem of ve- nous ulcer patients and its relation with sociodemographic, care characteristics and clinical.

\section{Methods}

A cross-sectional study was carried out based on a survey of people followed in the primary care services of Natal/RN, Brazil (15 Basic Health Units using the Family Health Strategy model). Data collection took place from February to April 2014 at the health unit or at the patient's home. Researchers were accompanied by a professional from the Family Health Strategy team, either nurse, nursing technician or community health agent.

The population was composed of people with venous ulcer and the sample corresponded to $44 \mathrm{pa}-$ tients followed by the Family Health Strategy teams during the period of data collection, who were selected for convenience, and who met the following inclusion criteria: presence of at least one venous ulcer diagnosed by the professionals of the family health team; perfect orientation and conditions to be interviewed; aged at least 18 years. Persons who presented ulcers of another etiology (arterial or mixed ulcers) were excluded.

Data were collected through an interview and physical examination of the lesion using the Self-esteem Scale ${ }^{(8)}$ and a form to evaluate the sociodemographic, care characteristics and clinical. The professional who accompanied the researchers also answered the questionnaire if the information needed was unknown to the interviewee, such as the type of ulcer and the training of the caregiver who performed the dressing.

The Rosenberg Self-esteem Scale is a generic instrument for the global evaluation of self-esteem that has been applied, translated, validated and adapted to several countries, including Brazil ${ }^{(9-10)}$. Although it has not been validated specifically for people with venous ulcers, it has already been used in this popu- 
lation $^{(6)}$. The Cronbach's Alpha test (alpha $=0.77$ ) was performed to verify the reliability of the Scale for the study sample. The version of the scale ${ }^{(10)}$ used in this study has a total score ranging from 0 to 30 , with 0 corresponding to the best state of self-esteem and 30 corresponding to the worst state ${ }^{(9)}$.

The sociodemographic variables surveyed were: sex; age group; marital status; schooling; occupation and per capita income. Regarding the care characteristics, the following factors were considered: the availability of products for the dressings, time of treatment of the ulcer in months ( $\geq 6$ months and $\leq 6$ months), training or lack of training of the professional/ caregiver who perform the dressing; guidance provided by the health professional such as the use of compressive therapy; lifting the lower limbs to an elevated position, and regular exercise, use of compressive therapy and number of consultations with the angiologist in the last year (none or $\geq 1$ ). The clinical variables were: recurrences ( $\geq 1$ or none); time of presence of the venous ulcer ( $>1$ year or up to 1 year); size of the venous ulcer (mean to large $>50 \mathrm{~cm}^{2}$ or small $\leq 50 \mathrm{~cm}^{2}$ of diameter); signs of infection (odor, purulent exudate, perilesional hyperemia or fever) and pain related to the ulcer.

The collected data were entered into a database and exported to a computerized software . Descriptive analyses were carried out with absolute and relative frequencies and inferential analysis for their crosses. The Shapiro-Wilk test was used to verify the normality of data. After checking normality, the t-test was used to check for differences between the means of the Rosenberg Self-esteem Scale in relation to sociodemographic, care characteristics and clinical, with a level of statistical significance of $p \leq 0.05$.

The study complied with the formal requirements contained in the national and international regulatory standards for research involving human beings.

\section{Results}

In the sociodemographic characterization of the sample, there was a predominance of females $(65.9 \%)$, over 60 years of age (59.1\%), married or common-law married (52.3\%), with low schooling (86.4\%), without occupation $(68.2 \%)$ and with income below one minimum wage (81.8\%).

As for the assistance provided, the following aspects were observed: availability of adequate products to the dressing (72.7\%); daily dressing performed predominantly by a trained professional or caregiver (65.9\%); non-use of compressive therapy (81.8\%); treatment of the lesion for more than or at least six months (77.3\%); absence of guidelines for the use of compressive therapy, lifting of lower limbs to an elevated position, and regular exercises (77.3\%); and no consultation with the angiologist in the last year (52.3\%).

As to clinical aspects of the venous ulcer, patients with recurrence (77.3\%), presence of local pain $(79.5 \%)$, more than 1 year of current venous ulcer (52.3\%), venous ulcer of medium to large size (54.8\%) and without signs of infection (61.3\%) prevailed.

The mean total self-esteem score in the sample studied was $9.3(\mathrm{SD}= \pm 5.1)$, with a median of 9.0 and a mode of 7.0. The individual scores obtained from the application of the scale ranged from 0 to 22 , of which $25(56.8 \%)$ were surveyed with a total score of up to $10,18(41.0 \%)$ between 11 and 21, and 1 (2.2\%) above of 21 .

The analysis of sociodemographic variables showed an association between self-esteem and marital status $(\mathrm{p}=0.016)$ and self-esteem and occupation $(\mathrm{p}=0.023)$. Married/common-law married individuals and active/working individuals showed higher self-esteem, as Table 1 shows. 
Table 1 - Sociodemographic characteristics of people with venous ulcers according to self-esteem scores

\begin{tabular}{|c|c|c|c|c|c|}
\hline \multirow{2}{*}{$\begin{array}{l}\text { Sociodemographic characteri- } \\
\text { zation }\end{array}$} & \multicolumn{5}{|c|}{ Rosenberg Self-esteem Scale } \\
\hline & n (\%) & $\begin{array}{l}\text { Shapiro- } \\
\text { Wilk }\end{array}$ & Levene & $\begin{array}{l}\text { T-test } \\
\text { Mean }\end{array}$ & $p$ \\
\hline \multicolumn{6}{|l|}{ Sex } \\
\hline Female & $29(65.9)$ & 0.954 & \multirow{2}{*}{0.22} & 9.8 & \multirow[t]{2}{*}{0.265} \\
\hline Male & $15(34.1)$ & 0.744 & & 8.3 & \\
\hline \multicolumn{6}{|l|}{ Age group (years) } \\
\hline From 60 & $26(59.1)$ & 0.813 & \multirow{2}{*}{0.66} & 9.9 & \multirow[t]{2}{*}{0.262} \\
\hline to 59 & $18(40.9)$ & 0.731 & & 8.3 & \\
\hline \multicolumn{6}{|l|}{ Marital status } \\
\hline Single/widowed/divorced & $21(47.7)$ & 0.728 & \multirow{2}{*}{0.310} & 11.2 & \multirow[t]{2}{*}{0.016} \\
\hline Married/common-law married & $23(52.3)$ & 0.619 & & 7.6 & \\
\hline \multicolumn{6}{|l|}{ Schooling } \\
\hline Up to elementary school & $38(86.4)$ & 0.414 & \multirow{2}{*}{0.740} & 9.2 & \multirow[t]{2}{*}{0.783} \\
\hline High school and higher education & $6(13.6)$ & 0.003 & & 9.8 & \\
\hline \multicolumn{6}{|l|}{ Occupation } \\
\hline Present & $14(31.8)$ & 0.867 & \multirow{2}{*}{0.256} & 6.8 & \multirow[t]{2}{*}{0.023} \\
\hline Absent & $30(68.6)$ & 0.575 & & 10.5 & \\
\hline \multicolumn{6}{|l|}{ Per capita income (Minimum wage*) } \\
\hline$<1$ & $36(81.8)$ & 0.786 & \multirow{2}{*}{0.936} & 9.3 & \multirow[t]{2}{*}{0.961} \\
\hline$\geq 1$ & $8(18.2)$ & 0.463 & & 9.4 & \\
\hline
\end{tabular}

The analysis of the care characteristics showed an association between self-esteem and use of compressive therapy $(\mathrm{p}=0.040)$ and treatment time $(p=0.014)$. Patients who used compressive therapy and had a treatment time of less than six months had better self-esteem scores (Table 2).
Table 3 shows the relationship between ulcer size and self-esteem ( $\mathrm{p}=0.010)$. Patients with medium or large ulcers had lower self-esteem compared to patients with small ulcers (Table 3).

Table 3 - Distribution of clinical aspects of the lesion according to self-esteem scores.

\begin{tabular}{|c|c|c|c|c|c|}
\hline \multirow{2}{*}{$\begin{array}{l}\text { Clinical aspects of the venous } \\
\text { ulcer }\end{array}$} & \multicolumn{5}{|c|}{ Rosenberg Self-esteem Scale } \\
\hline & n (\%) & $\begin{array}{l}\text { Shapiro- } \\
\text { Wilk }\end{array}$ & Levene & $\begin{array}{l}\text { T-test } \\
\text { Mean }\end{array}$ & $\mathbf{p}$ \\
\hline \multicolumn{6}{|l|}{ Recurrences } \\
\hline$\geq 1$ & $34(77.3)$ & 0.776 & \multirow{2}{*}{0.912} & 9.0 & \multirow{2}{*}{0.481} \\
\hline None & 10 (22.7) & 0.587 & & 10.3 & \\
\hline \multicolumn{6}{|l|}{ Time of current venous ulcer (year) } \\
\hline$>1$ & $23(52.3)$ & 0.781 & \multirow{2}{*}{0.964} & 10.1 & \multirow{2}{*}{0.232} \\
\hline Up to 1 & $21(47.7)$ & 0.761 & & 8.3 & \\
\hline \multicolumn{6}{|l|}{ Venous ulcer size } \\
\hline Medium to large $\left(>50 \mathrm{~cm}^{2}\right)$ & 17 (54.8) & 0.904 & \multirow{2}{*}{0.697} & 11.3 & \multirow{2}{*}{0.010} \\
\hline Small $\left(\leq 50 \mathrm{~cm}^{2}\right)$ & $14(45.2)$ & 0.567 & & 6.7 & \\
\hline \multicolumn{6}{|l|}{ Signs of infection } \\
\hline Present & 12 (38.7) & 0.896 & \multirow{2}{*}{0.316} & 12.5 & \multirow{2}{*}{0.080} \\
\hline Absent & $19(61.3)$ & 0.369 & & 7.3 & \\
\hline \multicolumn{6}{|l|}{ Pain } \\
\hline Present & 35 (79.5) & 0.741 & \multirow{2}{*}{0.672} & 9.4 & \multirow{2}{*}{0.790} \\
\hline Absent & $9(20.5)$ & 0.401 & & 8.89 & \\
\hline
\end{tabular}

Table 2 - Distribution of care characteristics according to self-esteem scores

\begin{tabular}{|c|c|c|c|c|c|}
\hline \multirow{2}{*}{ Care characteristics } & \multicolumn{5}{|c|}{ Rosenberg Self-esteem Scale } \\
\hline & n (\%) & Shapiro-Wilk & Levene & T-test Mean & p-value \\
\hline \multicolumn{6}{|c|}{ Time of treatment of the venous ulcer (months) } \\
\hline$\geq 6$ & $34(77.3)$ & 0.990 & \multirow{2}{*}{0.263} & 10.3 & \multirow{2}{*}{0.014} \\
\hline Up to 6 & $10(22.7)$ & 0.250 & & 5.9 & \\
\hline \multicolumn{6}{|c|}{ Availability of cleaning solutions and dressing coverages } \\
\hline No & $12(27.3)$ & 0.539 & \multirow{2}{*}{0.492} & 10.9 & \multirow{2}{*}{0.196} \\
\hline Yes & $32(72.7)$ & 0.508 & & 8.7 & \\
\hline \multicolumn{6}{|l|}{ Who performs the dressing } \\
\hline Untrained professional/caregiver & $15(34.1)$ & 0.885 & \multirow{2}{*}{0.205} & 9.6 & \multirow{2}{*}{0.777} \\
\hline Trained professional/caregiver & $29(65.9)$ & 0.461 & & 9.1 & \\
\hline \multicolumn{6}{|c|}{$\begin{array}{l}\text { Guidelines for the use of compression therapy, lower limb lifting and } \\
\text { regular exercises }\end{array}$} \\
\hline Absent & $34(77.3)$ & 0.758 & \multirow{2}{*}{0.371} & 9.2 & \multirow{2}{*}{0.831} \\
\hline Present & $10(22.7)$ & 0.735 & & 9.6 & \\
\hline \multicolumn{6}{|c|}{ Consultations with the angiologist in the last year } \\
\hline None & $23(52.3)$ & 0.921 & \multirow{2}{*}{0.325} & 9.0 & \multirow{2}{*}{0.734} \\
\hline$\geq 1$ & $21(47.7)$ & 0.694 & & 9.5 & \\
\hline \multicolumn{6}{|l|}{ Use of compressive therapy } \\
\hline No & $36(81.8)$ & 0.887 & \multirow{2}{*}{0.434} & 10.0 & \multirow{2}{*}{0.040} \\
\hline Yes & $8(18.2)$ & 0.210 & & 6.0 & \\
\hline
\end{tabular}




\section{Discussion}

The limitation was the type of study which implies reverse causality bias, which is an impossibility of clearly demonstrating the cause and effect, and the scale that has not been validated for people with venous ulcer, although the reliability test through Cronbach's alpha showed a good result.

In this study, people with venous ulcer were mostly female, aged over 60 years, with low level of education, income below one minimum wage, with partner and without occupation. This profile has been also found in analyses carried out in Brazil and Portu$\operatorname{gal}^{(3,11)}$.

The literature shows a higher occurrence of venous ulcers in the elderly, indicating that prevalence increases with age and that women are more likely to develop them, due to pregnancy repercussions, neuroendocrine disorders, varicose veins and chronic venous insufficiency ${ }^{(12)}$. Furthermore, women seek health services more often than men ${ }^{(13)}$.

The low educational level and the low income of the participants are sociodemographic characteristics present in the studied sample. This may predispose patients to development of injuries, lack of access to specialized health services and the financial imbalance of the family due to the expenses implied in the treatment ${ }^{(3,14)}$.

The analysis of the relationship between self-esteem and sociodemographic variables identified positive associations with marital status and occupation. The better self-esteem in people with some sort of occupation shows that their insertion in the market is important for their adaptation and to support the family, since these activities make them feel useful, capable, part of a social cycle with a consequent better appreciation of themselves ${ }^{(15)}$.

The presence of a partner is a positive factor for people with venous ulcer because this can help overcome difficulties and activities of daily living, as well as ease the limitations and provide day-to-day support. These aspects may explain the best self-esteem among people who live with a partner ${ }^{(12)}$.

In the analysis, the treatment of the current ulcer of less than six months and the use of compressive therapy were identified as positive factors to a better self-esteem. Treatment in the initial phase leads to a greater hope of cure of the lesion; inturn, individuals who have venous ulcers for more than one year feel powerless and hopeless about their healing ${ }^{(16)}$. Therefore, these feelings can lead people to negative self-assessments, reflecting on their self-esteem.

Studies have shown that venous ulcers heal faster using compression therapy because compression reduces edema, improves venous return, facilitates ulcer healing, reduces pain and prevents recurren$c \mathrm{e}^{(1-2,17-18)}$. It is expected, therefore, that the use of compression influenced a better self-esteem.

The guarantee of the supply of adequate materials to carry out the dressings is the responsibility of public health services. Nevertheless, an opposite situation has been observed in almost the entire Brazilian scenario, with an absence of therapeutic continuity due to lack of products or inadequate purchase ${ }^{(5)}$. In spite of this, in this study, the service had the materials to perform the dressings at its disposal, and the majority of the professionals/caregivers had specific knowledge about the care of ulcers. These factors are important because without the material and the knowledge, a generalized care is provided for all types of lesions and the conducts are mistaken, causing relapses and, consequently, longer healing time.

It is important to note that despite the care of trained professionals, guidelines for the use of compressive therapy, lower limb lifting, and regular exercise were not mentioned as resgularly provided. In line with these data, it has been reported in other studies that, although knowing the guidelines regarding prevention against recurrences, few nurses performed actually provide them to patients ${ }^{(17)}$.

A research carried out the professional characterization of nursing workers who care for people with vascular ulcers. The study showed a lack of knowledge of specific recommendations in the care of this 
clientele (compression therapy, exercises and lifting of the lower limbs, among others) and flaws in the training/qualification of the team because of scarce investments in this area ${ }^{(19)}$.

In this sense, it is important to emphasize the need for continuous improvement of professionals and we reiterate that care must be multiprofessional and encompass comprehensive assessments and interventions (including the self-esteem of patients) and not only clinical aspects of the injury ${ }^{(19)}$.

The findings of this study also point out the need for teams to develop strategies to avoid recurrences. Previous history of venous ulcer increases the chance of recurrence, with a rate of $69.0 \%$ after one year of healing of the lesion ${ }^{(1,4)}$.

As for the time of presence of the current ulcer greater than one year, this is related to the chronicity of the injury and the difficulties of healing. This difficulty involves a number of factors, as for example wound conditions, treatment, care with aseptic standards, dressing technique and the choice of products used, besides the presence of other concomitant chronic diseases ${ }^{(5)}$. The lack of access to specialized services, such as angiology, also hinders the provision of care; the assessment and systemic approach may occur at a late moment in which the ulcers are already in an advanced stage $\mathrm{e}^{(14)}$.

A positive association was identified between self-esteem and small ulcer size. A study that compared the dimensions of the ulcers with the healing time reported that the bigger the size of the ulcer, the longer is the healing time. Thus, size represents a risk factor for delayed cicatrization ${ }^{(4,18)}$.

Although not statistically significant, the self-esteem of patients with signs of infection and pain was lower than that in patients without pain and signs of infection. It is imperative that the team pay attention to the assessment of pain, since this is a frequent symptom in this population. Besides limiting the realization of activities of daily living, pain causes trouble to work activities, leading to the establishment of distance from social contexts, which may ultimately affect the quality of life ${ }^{(4)}$. An analysis found that pain is one of the main symptoms mentioned in studies of quality of life linked to living with venous ulcers ${ }^{(20)}$. It is therefore necessary to provide emotional support and mechanisms to face this situation, because in addition to all the aforementioned changes, this population also feels powerless and hopeless regarding the healing of the wound ${ }^{(12)}$. Thus, studies that investigating the self-esteem of people with venous ulcer are important. In the present research, the patients' self-esteem proved to be good, which was somehow unexpected because the literature reports exactly the opposite: the individuals verbalize and demonstrate little or no satisfaction with their self-esteem ${ }^{(6-7,10)}$.

A review that evaluated the impact of venous ulcers on various psychoemotional characteristics identified depression, low self-esteem, self-loathing, social isolation and low quality of life as the most frequent ${ }^{(20)}$. The result of this study suggests that, although susceptible to low self-esteem, patients are able to maintain a positive self-assessment ${ }^{(6)}$. Individuals with venous ulcers are able to cope with the chronic injury and feel as equal and important as other people.

We emphasize that venous ulcers constitute a serious public health problem and their psychological and social effects are often neglected. In this perspective, the results of the present study may contribute to the improvement of care for people with venous ulcer, since it made it possible to identify the main sociodemographic, clinical and care aspects that affected the self-esteem of this population.

The self-esteem of people with venous ulcers was satisfactory/high. However, in view of the complexity of the lesion and its consequences in the patient's life, comprehensive attention is essential to improve the individual's health ${ }^{(5)}$. We suggested deepening the investigation of the influence of these variables on self-esteem, in order to reinforce the discussion and build instruments that better evaluate the peculiar aspects of people with venous ulcers. 


\section{Conclusion}

The self-esteem of patients with venous ulcers was satisfactory/high, especially among those with partner, occupational activity, making use of compressive therapy, at the initial phase of the treatment and who had small ulcers.

\section{Collaborations}

Souza AJG, Campos SMDL and Queiroz CG contributed to the conception and design, analysis and interpretation of data and writing of the article. Salvetti MG, Torres GV and Costa IKF Costa contributed to the conception and design, analysis and interpretation of data, relevant critical review of the intellectual content and final approval of the version to be published.

\section{References}

1. O'Donnell Jr TF, Passman MA, Marston WA, Ennis WJ, Dalsing M, Kistner RL, et al. Management of venous leg ulcers: clinical practice guidelines of the Society for Vascular Surgery (C) and the American Venous Forum. J Vasc Surg. 2014; 60(Suppl2):3-59. http://dx.doi.org/10.1016/j. jvs.2014.04.049

2. Thomas DR. Managing venous stasis disease and ulcers. Clin Geriatr Med. 2013; 29(2):415-24. http://dx.doi.org/10.1016/j.cger.2013.01.006

3. Dias TYAF, Costa IKF, Liberato SMD, Souza AJG, Mendes FRP, Torres GV. Quality of life for venous ulcer patients: a comparative study in Brazil/ Portugal. Online Braz J Nurs. 2013; 12(3):491-500. http://dx.doi.org/10.5935/1676-4285.20134344

4. Gohel MS, Poskitt KR. Chronic ulceration of the leg. Surgery (Oxford). 2013; 31(5):224-8. http:// dx.doi.org/10.1016/j.mpsur.2013.02.004

5. Oliveira BGRB, Castro JBA, Granjeiro JM. Epidemiologic and clinical overview of patients with chronic wounds treated at an outpatient clinic. Rev Enferm UERJ [Internet]. 2013 [cited 2017 jan. 13]; 21(esp.1):612-7. Available from: http://www.e-publicacoes.uerj.br/index.php/ enfermagemuerj/article/view/10035/8127
6. Salomé GM, Blanes L, Ferreira LM. The impact of skin grafting on the quality of life and self-esteem of patients with venous leg ulcers. World J Surg. 2014; 38(1):233-40. doi: 10.1007/s00268-0132228-x

7. Aguiar ACSA, Sadigursky D, Martins LA, Menezes TMO, Santos ALS, Reis LA. Social repercussions experienced by elderly with venous ulcer. Rev Gaúcha Enferm. 2016; 37(3):1-6. http://dx.doi. org/10.1590/1983-1447.2016.03.55302

8. Rosenberg M. Society and the adolescent selfimage. New Jersey: Princeton University Press; 1965.

9. Hutz CS, Zanon C. Revisão da adaptação, validação e normatização da escala de autoestima de Rosenberg. Aval Psicol [Internet]. 2011 [citado 2017 jan. 12]; 10(1):41-9. Disponível em: http://pepsic. bvsalud.org/pdf/avp/v10n1/v10n1a05.pdf

10. Dini GM, Quaresma MR, Ferreira LM. Translation into Portuguese, Cultural Adaptation and Validation of the Rosenberg Self-esteem Scale. Rev Soc Bras Cir Plást [Internet]. 2004 [cited 2017 Jan. 12]; 19(1):41-52. Available from: http://www. rbcp.org.br/imageBank/PDF/19-01-04pt.pdf

11. Medeiros ABA, Andriola IC, Fernandes MICD, Silva BBL, Sá JD, Lira ALBC. Association of socioeconomic and clinical factors and tissue integrity outcome of patients with ulcers. Rev Enferm UFPE on line [Internet]. 2013 [cited 2017 Jun 13]; 7(8):52204. Available from: http://www.revista.ufpe.br/ revistaenfermagem/index.php/revista/article/ view/4251

12. Silva MC, Couto EL. Insuficiência venosa crônica: diagnóstico e tratamento clínico. In: Maffei FHA, Lastória S, Yoshida WB, Rollo HA, Giannini M, Moura R. Doenças vasculares periféricas. Rio de janeiro: Guanabara Koogan; 2015. p.2029-37.

13. Silva MH, Jesus MCP, Merighi MAB, Oliveira DM, Biscotto PR, Silva GPS. The daily life of men who lives with chronic venous ulcer: phenomenological study. Rev Gaúcha Enferm 2013; 34(3):95-101. http://dx.doi.org/10.1590/ S1983-14472013000300012 
14. Malaquias SG, Bachion MM, Sant'Ana SMSC, Dallarmi CCB, Lino Junior RS, Ferreira OS. People with vascular ulcers in out patient nursing care: a study of sociodemographic and clinical variables. Rev Esc Enferm USP. 2012; 46(2):302-10. http://dx.doi.org/10.1590/S008062342012000200006

15. Silva DC, Budó MLD, Schimith MD, Ecco L, Costa IKF, Torres GV. Experiences constructed in the process of living with a venous ulcer. Cogitare Enferm. 2015; 20(1):13-9. dioi: http://dx.doi. org/10.5380/ce.v20i1.37784

16. Alves SG, Gardona RGB, Reis BC, Vilela LHR, Salomé GM. Association of sociodemographic effects and injury to feelings of power lessness and hope in individuals with venous ulcers. Rev Soc Bras Cir Plást [Internet]. 2013 [cited 2017 Jun. 13]; 28(4):672-80. Available from: http://www. rbcp.org.br/details/1466/pt-BR/associacaodos-fatores-sociodemograficos-e-da-lesaorelacionados-ao-sentimento-de-impotencia-eesperanca-em-individuos-com-ulcera-venosa
17. Peres GA, Zuffi FB, Poggetto MTD. Prática dos enfermeiros nos cuidados às pessoas com úlcera venosa na saúde da família. Saúde Coletiva Dig [Internet]. 2013 [citado 2017 abr. 20]; 1(1):3741. Disponível em: http://www.redalyc.org/ html/842/84228211007/

18. Afonso A, Barroso P, Marques G, Gonçalves A, Gonzalez $\mathrm{A}$, Duarte $\mathrm{N}$, et al. Úlcera crónica do membro inferior - experiência com cinquenta doentes. Angiol Cir Vasc. 2013; 9(4):148-53. https://doi. org/10.1016/S1646-706X(13)70035-1

19. Santana AC, Bachion MM, Malaquias SG, Vieira F, Carneiro DA, Lima JR. Caracterização de profissionais de enfermagem que atendem pessoas com úlceras vasculares na rede ambulatorial. Rev Bras Enferm. 2013; 66(6):821-26. http://dx.doi. org/10.1590/S0034-71672013000600002

20. Maddox D. Effects of venous leg ulceration on patients' quality of life. Nurs Standard. 2012; 26(38):42-9. doi: https://doi.org/10.7748/ ns2012.05.26.38.42.c9111 